\title{
The Use of Lean Six Sigma to Improve Key Performance Indicators on The Plant Division of PT. PPN
}

\author{
Widhi Setya Wahyudhi ${ }^{1}$, Athor Subroto ${ }^{1 *}$ \\ ${ }^{1}$ Department of Management, Faculty of Economics and Business, Universitas Indonesia \\ Email: athor.subroto@yahoo.com
}

\begin{abstract}
This paper is aimed to analyze the applicability of the Lean Six Sigma in term of itscapability to support efficiency and performance in the maintenance division of a coal mining contractor. The data collection was done in 5 months, from October 2016 until February 2017 taken from the company data base - computerized maintenance management system (CMMS). The Lean Six Sigma is an approach that provides a structured approach to resolve the problem through the implementation of five phase of six sigma methodology; Define, Measure, Analyze, Improve and Control (DMAIC). Six Sigma had been applied to focused on the quality to ensure the system maintenance activities are more effective and efficient to obtain an optimal maintenance management system by which capable to create a competitive advantage for the companies. Some performance improvements have been achieved such as the improvement on the key performance indicator namely Re-do Periodical Service (Re-do PS). Re-do PS value for PC1250 and HD4657R decreased to $0 \%$. The other improvement can be seen on the Process Performance Index (Ppk) value of PC 1250 that increased to 8.30 and Ppk value of HD4657R that increased to 18.32 . Overall, the financial performance has also increased, by saving the cost of maintenance as much as three billion rupiahs for HD4657R and 16 billion rupiahs for PC1250.
\end{abstract}

Keywords: Lean Six Sigma; Computerized Maintenance Management System (CMMS); Heavy Equipment; Sustainable Competitive Advantage.

\section{Introduction}

PT PPN is one of the coal mining contractor company that became the market leader in Indonesia. In an economic climate that tends to decrease causes coal prices also decreased (Rida, 2016; APBI, 2016, Roberson, 2016). PT. PPN can still maintain its market leadership and defeat the existing competitors it is necessary to have a highly effective operational strategy. One of the divisions in the operational function is Plant division or heavy equipment maintenance division in PT PPN. This division has a role to maintain the availability and reliability of existing heavy equipment, to be ready to operate in the process of coal harvesting (Yulianto, 2015). 


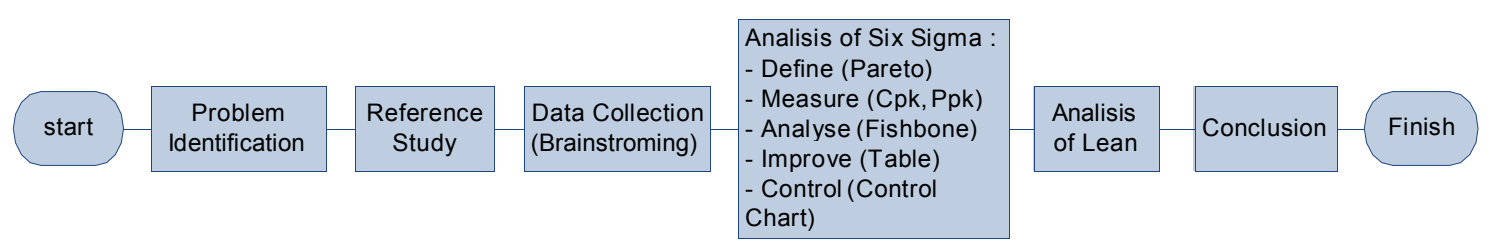

Figure 1. Research Framework

\section{Methods}

Our step-by step framework in conducting this research can be seen in the figure above:

In the early stage of problem formulation, this study utilized direct observation on the site. We identified problems that arise or being faced by the company which is eventually become the objective of this research (Zapartas, 2012). We then collected primary data through brainstorming in a small focus group with the relevant division team: System Development and Technical Officers.

Concerns came up from the discussion that to achieve the optimal maintenance conditions required a proper strategy for the level of readiness of tools used by the production can reach its maximum point. According to Zapartas (2012), the method used for this concern is a combination of lean method and six sigma method.

One of the properties of Six Sigma method is $\sigma$ (sigma). Sigma is the value used to identify the variation of a process. The rate of a sigma indicates how often the defect occurs and the higher the sigma value, the less likely it is the defect of a production process (Pedja, 2005; Robert, 2003). The purpose of Six Sigma is to identify and eliminate non-conformances and defects in all services in the form of services and products through discipline in data usage, statistical analysis and thought process (Chambers, 2006; Balueh, 2012; Zapartas, 2012). There are five phases of sigma application:

\subsubsection{Define phase}

Zapartas (2012) urges that in this phase, the researcher must define the problem and purpose of a research. Accordingly, we use the bottom-up approach for the project improvement, which means we identify some improvement opportunities depicted from the indicators obtained from the Plant division. These indicators can be Key Performance Indicators that have been determined by the Plant Division and Critical to Quality (CTQ) of the maintenance performance (Al, 2005).

\subsubsection{Measure Phase}

After selecting key performance indicators, the next stage is testing the obtained data for the normality to determine the type of data distribution (Zapartas, 2012). The type of distribution of processed data should indicate a normal distribution characteristics. Using Minitab v. 17, the distribution from the data can be determined whether it follows a specific distribution or not with a certain mean (Colton, 2013). Analytical phase-by observing the performance index (Ppk) and capability index (Cpk) from this analysis will determine the type of variation of existing data level whether variation of the data is still in the range of USL (Upper Specification Limit) \& LSL (Lower Specification Limit) (Bass, 2007; Hendradi, 2006; Moubray, 2011). 


\subsubsection{Analyze Phase}

The analytical tool to be used in this phase is fishbone diagram with ideas elicitation by brainstorming (Clark, 2011; Baumgartner, 2012). Fishbone diagram is one of the analytical tools to identify the root causes that exist so that can provide insight of the cause of a problem that appears in heavy equipment maintenance activities which based on the value stream map (Mostafa, 2015b; Kannan, 2009a; Kannan, 2009b).

\subsubsection{Improve Phase}

In this phase, later the researcher identified the key performance indicators that are observed, whether there is improvement of performance after the improvement activity. In this phase, in addition to perceived key performance indicators that there will also be seen variations of data. The process of data normality test and Ppk as well as Cpk analysis is needed to see whether the tested data has variations in data that has a small range and in the USL \& LSL range (Gulati, 2013; Bass, 2007; Hendrardi, 2006).

\subsubsection{Control Phase}

In this research will be an approach using Statistical Process Control Chart (SPC) so that the improvement activities we do remain sustainable and as expected.

We then take the benefit of step of brainstorming according to Baumgartner (2012) and Clark (2011) who give emphasis in determining the root of the problem and the idea of improvement by an approach using a brainstorming methodology. Where the brainstorming method is done to get the actual conditions that occur in the field. Brainstorming method is done by the function of direct related positions in the maintenance activities of heavy equipment unit in which each people has the expertise in their respective fields.

Based on the formulation of the problems and backgrounds that have been highlighted above where some scholar did the similar work like Tenera (2013), Youssouf (2014), Khaled (2013) and Mostafa (2015a,b) as well as Omar (2014) in the different sector, the purpose of this study are two folds; 1 . To apply lean six sigma methodology and 2 . To analyze the results of lean six sigma implementation in PT PPN Plant division.

\section{Results and Discussions}

\subsection{Define Phase}

In the current economic climate tends to decline from first quartile 2016 make coal prices also decline (Investmentmine, 2016; APBI, 2016). To maintain its market leadership and outperform the existing competitors, PT. PPN must search and develop strategic improvement to maintain its robustness in the market to be more efficient in its operation (Jacobs, 2011).

One of the divisions in the operational function is Plant division or heavy equipment maintenance division in PT PPN. This division has a role to maintain the readiness (availability) and reliability (Reliability) of existing heavy equipment, to be ready to operate in the process of coal harvesting (Gulati, 2013).

In the Plant division of PT. PPN there are several key performance indicators (KPI) used to review the performance or success of Plant Division in supporting the production process in the field such as Mean Time Between Failure (MTBF), Physical Availability (PA) and Re-do 


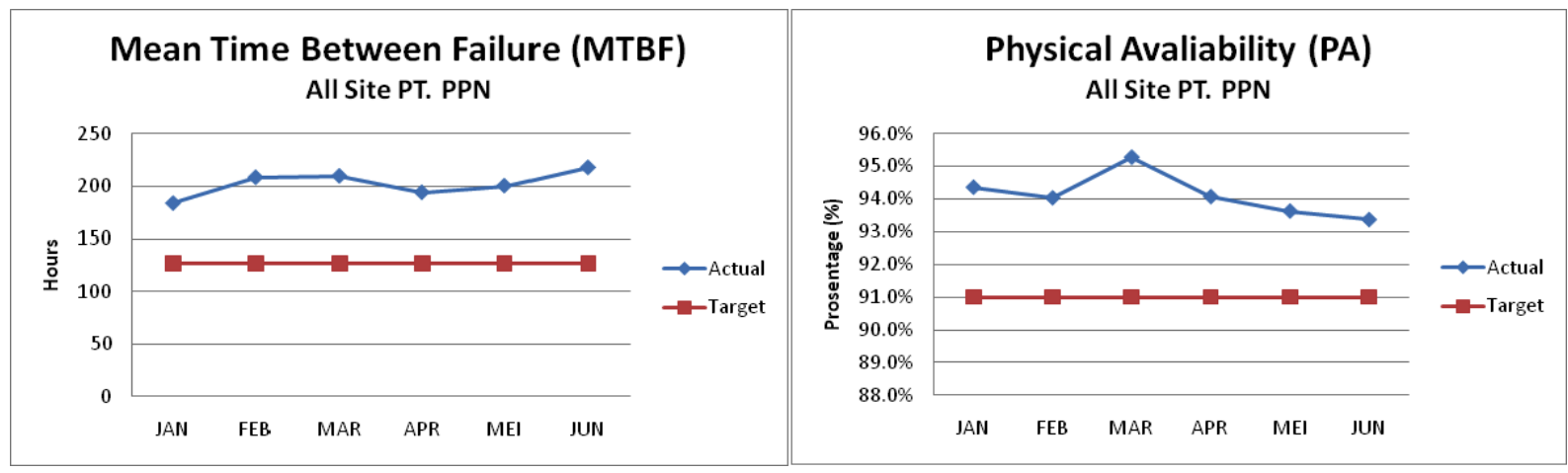

Figure 2. Key Performance Indicators All Site
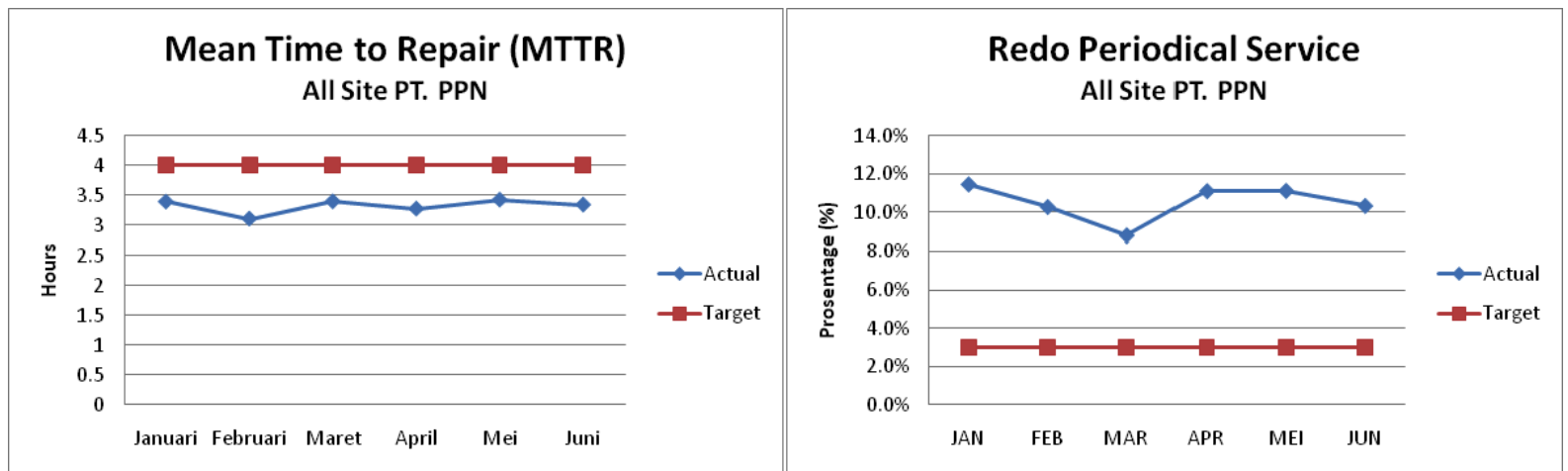

Figure 3. Key Performance Indicators All Site

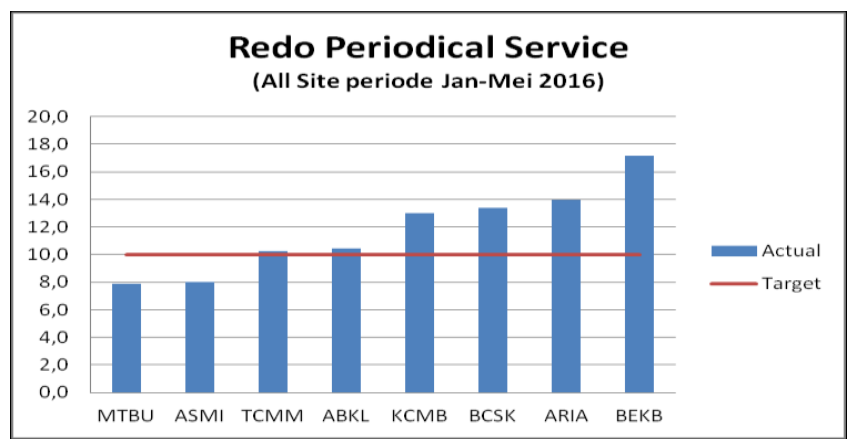

Figure 4. Redo Periodical Service (Re-do PS) All Site

PS. This Key Performance Indicators (KPI) selection due to this KPI is directly related to the equipment performance and affect to the operational performance. This key performance indicators (KPI) is associated with maintenance quality.

From the results of key performance indicator (KPI) above shows that MTBF, MTTR and PA have shown positive performance with values above the target set. However, the KPI Re-do PS has not been achieved at the desired performance from January to June. The KPI has never been below the expected target of below $3 \%$.

Redo periodical service is one of the measurement of quality of maintenance system in PT. PPN. After that determined one of the work area to be pilot project implementation of leansix sigma analysis. The initial stage in determining the pilot project is to evaluate the redo PS value at all PT PPN sites. 

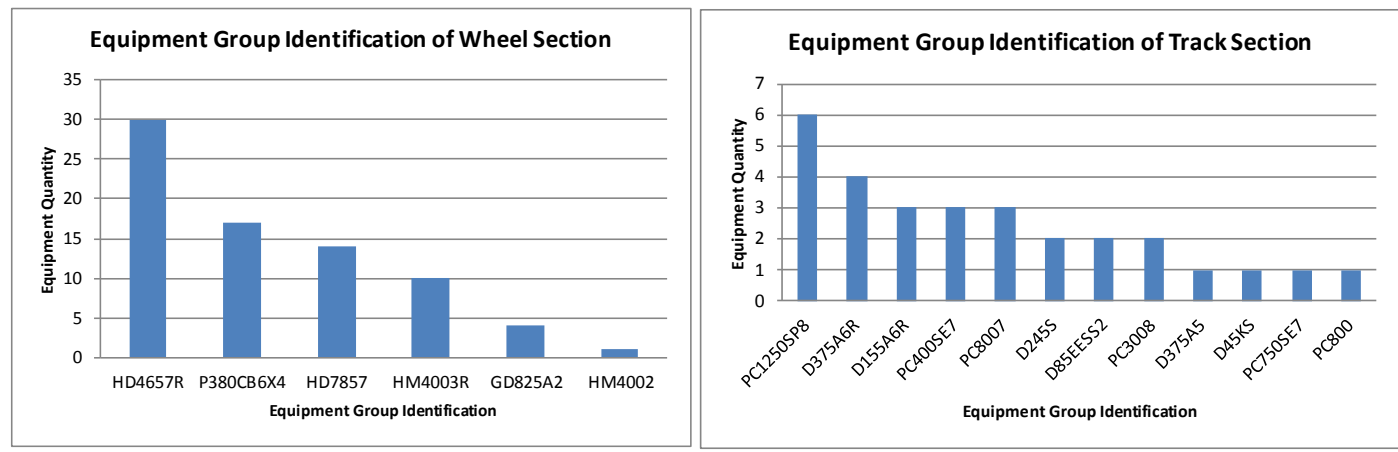

Figure 5. Equipment PopulationSite BEKB

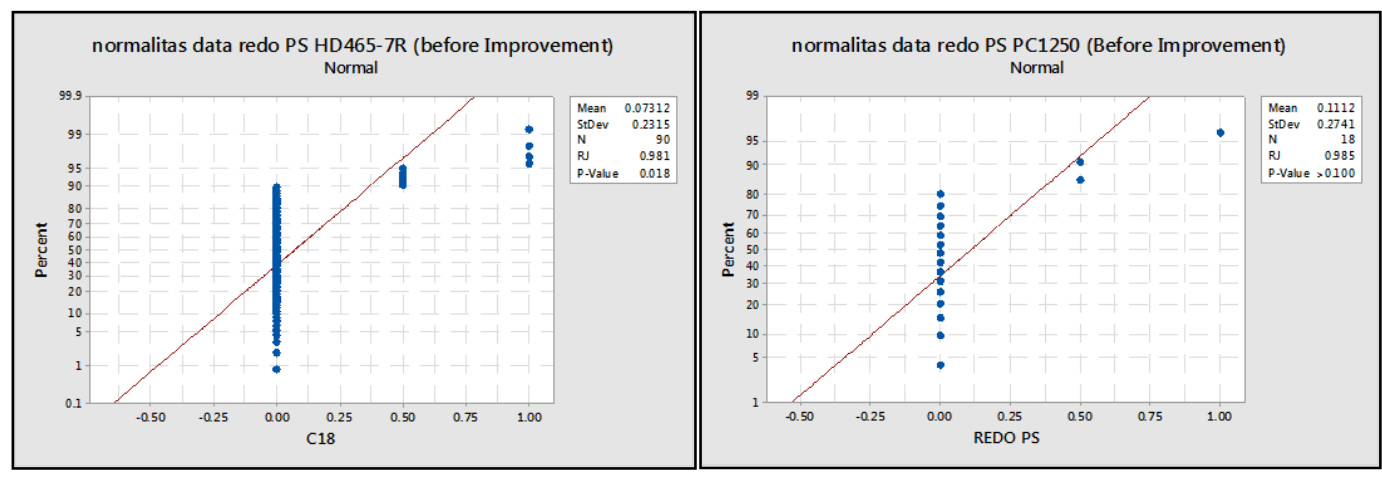

Figure 6. Normality Test HD 465-7R \& PC1250

From the redo, PS evaluation across the site, it is found that site that has the poorest quality of maintenance performance is the Bharinto site (BEKB). From these results, it was decided that the BEKB site as the pilot project implementation of lean six sigma analyses (Zapartas, 2012), the next stage is to determine the type of heavy equipment that will be the main pilot project to be analyzed that is relied on the below figure.

Isight comes from the Figure 5, we selected two main EGIs that are EGI HD465-7R and EGI PC1250 for the implementation of lean six sigma analyses in the division of PT PPN Plant.

\subsection{Measure Phase}

Parameters to be measured on this site include the performance of Redo PS located on the Bharinto site. In the preliminary data test found that the data Redo PS has normal data, this is indicated by the value of $p$-value greater than 0.005 .

After testing the data normality and expressed the data is normally distributed then the capillary testing process conducted in the period October to December 2016. In the capability test process performance of PS HD465-7R redo obtained Ppk value of -0.06 and Ppk value of -0.10 for PS12 PC1250 redo performance where the value of Ppk showed that the performance of equipment on the Re-do PS parameter in Bharinto (BEKB) is needed to be improved. 


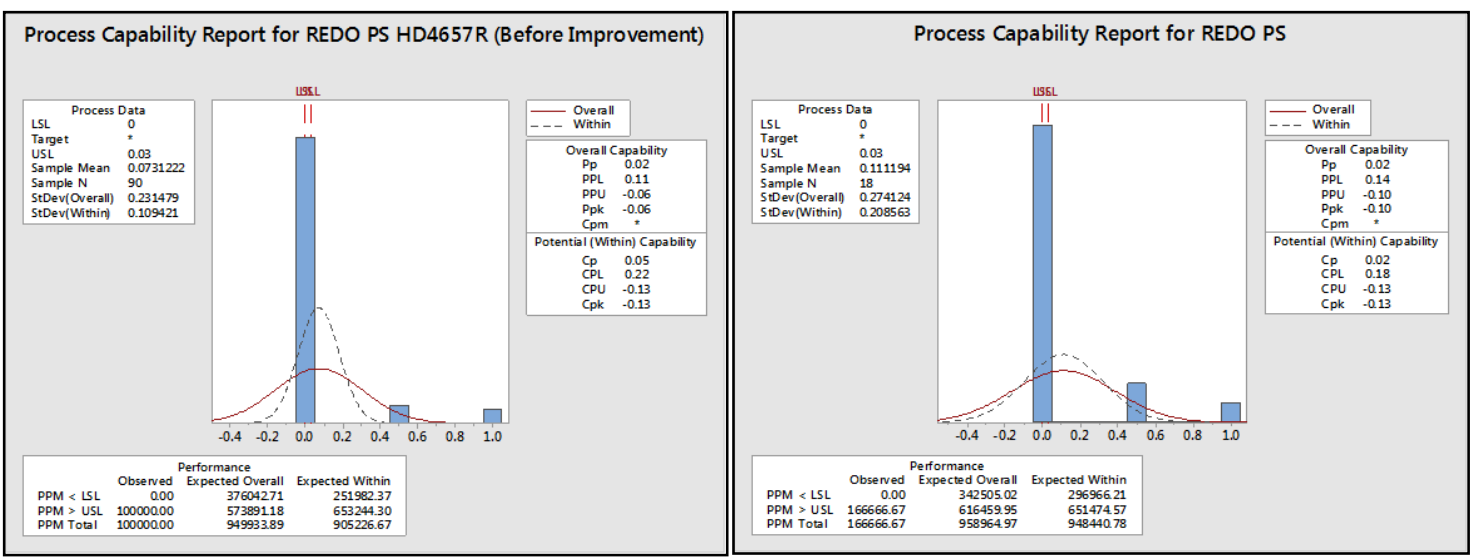

Figure 7. Capability Analysis HD 465-7R \& PC1250

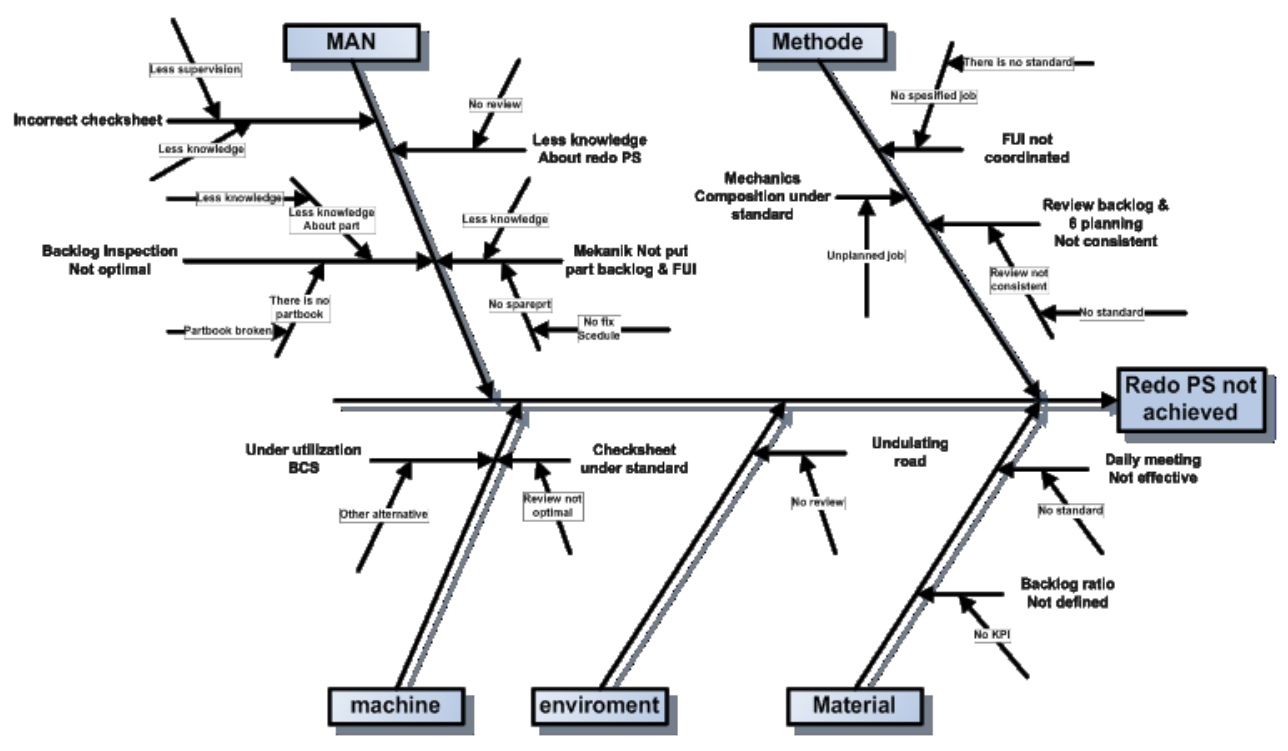

Figure 8. Fishbone Diagram

\subsection{Analyze Phase}

The method employed in the process of analyzing the main causes of failure and low performance of two parameters is analyzed by using fishbone diagram (Zapartas, 2012). Where the results of this fish bone diagram obtained through brainstorming method by some competent individual responsible for the field (System Development and Technical Officer) division Plant PT PPN (Baumgartner, 2012). Brainstorming is carried out within a team from System Development Officers and Technical Officers, where brainstorming is attended by 9 people to find the root cause of the problem from every condition from each side such as man, method, material, machine and environment.

\subsection{Lean Analyses}

Smith (2004) urges that some waste based on the above value stream mapping that can be identified and in accordance with the concept of Lean, reduce waste, among others: 
Table 1. Solution Alternative

\begin{tabular}{|c|c|c|c|}
\hline No & Problem & Caused & Solution Alternative \\
\hline 1 & $\begin{array}{l}\text { Mechanics do not fill } \\
\text { Checksheet PS in accordance } \\
\text { with system management } \\
\text { standards }\end{array}$ & Less of Skill \& knowledge & $\begin{array}{l}\text { Plant Instructure (PI) and Plant engineer (PE) perform OJI to } \\
\text { mechanics to carry out inspection activities / PPM (1x per } \\
\text { week) and FUI / backlog activity (by case critical activity) }\end{array}$ \\
\hline \multirow[b]{2}{*}{2} & \multirow{2}{*}{$\begin{array}{l}\text { Backlog inspection does not } \\
\text { run optimally }\end{array}$} & part book broken & Making digital part book \\
\hline & & Less of Skill \& knowledge & $\begin{array}{l}\text { Plant Instructure (PI) and Plant engineer (PE) perform OJI to } \\
\text { mechanics to carry out inspection activities }\end{array}$ \\
\hline \multirow{3}{*}{3} & \multirow{3}{*}{$\begin{array}{l}\text { Mechanics does not install part } \\
\text { backlog or part FUI }\end{array}$} & \multirow[t]{2}{*}{$\begin{array}{l}\text { Standardized of backlog part } \\
\text { does not exist }\end{array}$} & $\begin{array}{l}\text { Plant Engineer is required to provide information regarding } \\
\text { the progress of FUI activities executed on the previous daily } \\
\text { PS and provide critical FUI related information on the } \\
\text { service in meetings of mushrooms \& P5M }\end{array}$ \\
\hline & & & $\begin{array}{l}\text { Conducting a meeting between mechanic, GL \& engineer to } \\
\text { create JSS (Job Schedule Sheet) max H-1 before service } \\
\text { takes place }\end{array}$ \\
\hline & & $\begin{array}{l}\text { Understanding in flow backlog } \\
\text { process is still not uniform }\end{array}$ & $\begin{array}{l}\text { Planner to socialize / refresh to increase the competence or } \\
\text { understanding of mechanical related Standard Operating } \\
\text { Procedure (SOP) Backlog during meeting RD }\end{array}$ \\
\hline 4 & $\begin{array}{l}\text { Ignorance of interest discusses } \\
\text { redo PS }\end{array}$ & $\begin{array}{l}\text { No review and follow-up } \\
\text { periodically regarding PS redo } \\
\text { performance }\end{array}$ & $\begin{array}{l}\text { Group leaders are required to implement Coaching \& } \\
\text { Counseling against mechanics who do not work on FUI or } \\
\text { backlog }\end{array}$ \\
\hline \multirow[t]{2}{*}{5} & \multirow{2}{*}{$\begin{array}{l}\text { The mechanical composition } \\
\text { conforms to the standard }\end{array}$} & \multirow{2}{*}{$\begin{array}{l}\text { Mechanics do not work in } \\
\text { accordance with the planning } \\
\text { that has been compiled }\end{array}$} & $\begin{array}{l}\text { Group leaders are required to write down the name of the } \\
\text { mechanic and detail of the allocation per job (Backlog, } \\
\text { Service or FUI) }\end{array}$ \\
\hline & & & $\begin{array}{l}\text { Special mechanical formation for service activity \& } \\
\text { mechanical allocation for service fix activity }\end{array}$ \\
\hline 6 & $\begin{array}{l}\text { Review backlog \& } 6 \text { parameter } \\
\text { planning is not run periodically }\end{array}$ & $\begin{array}{l}\text { There is no standardized } \\
\text { review mechanism of backlog } \\
\text { ratio \& } 6 \text { parameter planning }\end{array}$ & $\begin{array}{l}\text { Plant Engineer is required to provide information regarding } \\
\text { the progress of FUI activities }\end{array}$ \\
\hline \multirow{2}{*}{7} & \multirow{2}{*}{$\begin{array}{l}\text { There is no mechanism in } \\
\text { monitoring the backlog ratio }\end{array}$} & \multirow[t]{2}{*}{$\begin{array}{l}\text { Still no measurement of } \\
\text { performance backlog ratio }\end{array}$} & $\begin{array}{l}\text { Making a new key performance indicator that is monitoring } \\
\text { the backlog ratio }\end{array}$ \\
\hline & & & $\begin{array}{l}\text { Incorporate KPI backlog ratio as one of the items to be } \\
\text { conducted by PMMS audit mechanism. }\end{array}$ \\
\hline 8 & $\begin{array}{l}\text { Technology or Applications are } \\
\text { not used optimally }\end{array}$ & $\begin{array}{l}\text { There is still no standard } \\
\text { operating procedure in } \\
\text { utilizing BCS applications }\end{array}$ & $\begin{array}{l}\text { The Mandatory Program that the source data for the backlog } \\
\text { only comes from the BCS }\end{array}$ \\
\hline 9 & $\begin{array}{l}\text { There is still an undulating path } \\
\text { and the equipment condition is } \\
\text { not used according to the } \\
\text { procedure }\end{array}$ & $\begin{array}{l}\text { No team has been concerned } \\
\text { about the review of operational } \\
\text { conditions }\end{array}$ & $\begin{array}{l}\text { The establishment of a special team to conduct road } \\
\text { condition review activities periodically }\end{array}$ \\
\hline
\end{tabular}




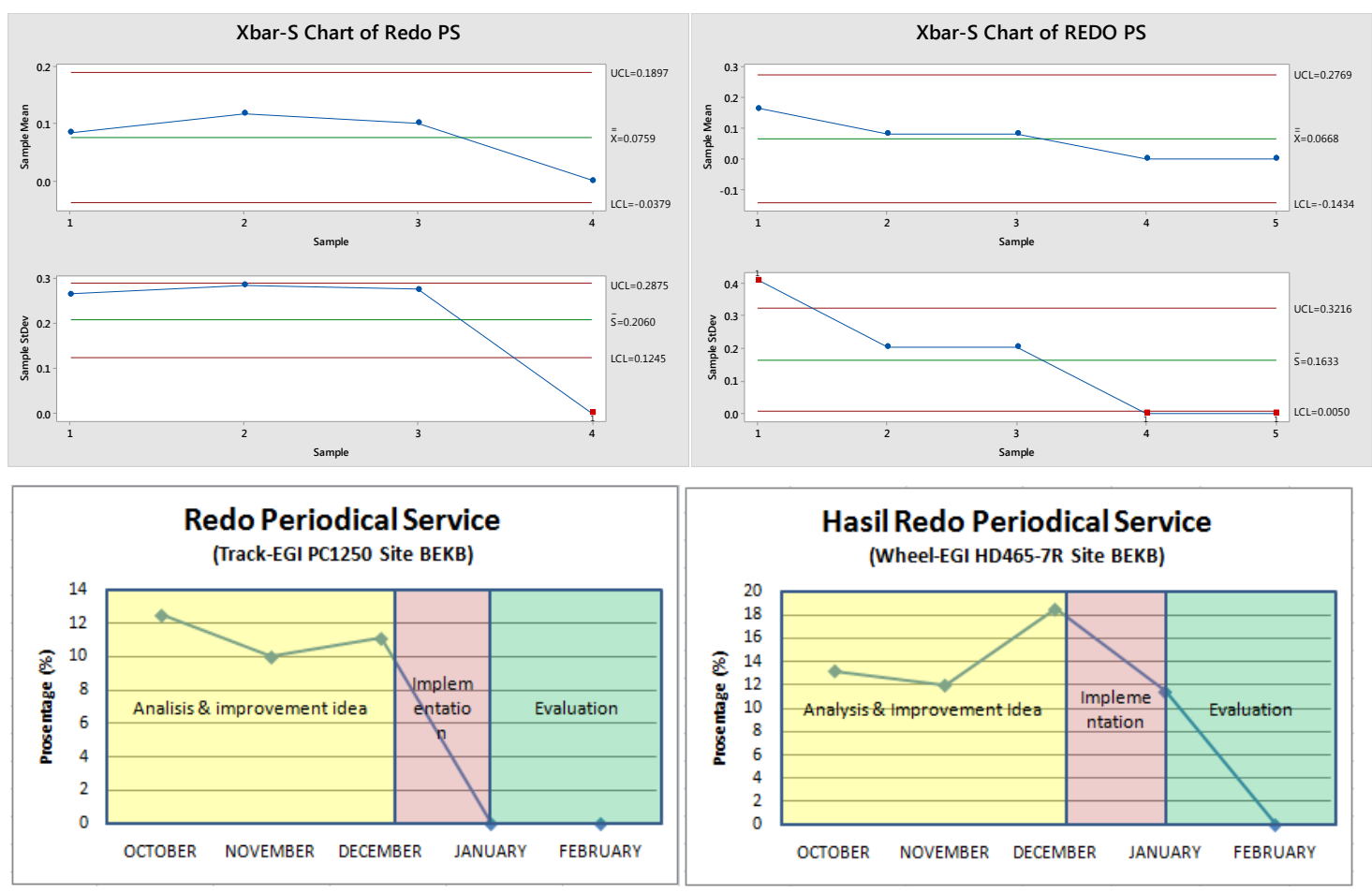

Figure 9. Control Chart HD465-7R \& PC1250

i. Unnecessary motion. This Waste due to movement is caused because there are some things when maintenance activities take place not well prepared like equipment (tools) that are not well prepared.

ii. Unproductive maintenance This waste is caused by the process of over-treatment (over), this activity can be a job that has the frequency of inspection equipment that should be low but done with high frequency.

iii. Ineffective data management This waste occurs when there are some technologies that already exist but not used optimally.

\subsection{Improve Phase}

From the analysis of fish bone diagram are seen some root causes to identify some alternatives for improvement. Finding alternative solution or improvement activity as the next step is done by Brainstorming method with a relevant team in the site (Plant System Development \& Technical Officer) in Plant Division of PT PPN. Ideas coming from the brainstorming for the solution alternatives is listed on the Table 1 below:

From the charts above, it shows that Re-do PS performance has better performance after the implementation improvement activity, where seen that graph is still in range of LSL and USL and trend of redo data PS progresses to position of zero value which has meaning number of unscheduled Breakdown that occurs after the quality of care / maintenance of equipment is getting smaller so the quality of care is getting better.

From the above table, we have some performances improvement at one of key performance indicators, that key performance indicators is Re-do PS. Re-do PS value for PC1250 and HD4657R decreased to 0\%, Ppk value of PC 1250 increased to 8.30 and Ppk value of HD4657R increased to 18.32. Beside that it have some potential benefit for financial performance, it have 3 Billion rupiah for HD4657R and 16 Billion rupiah for PC1250. 
Table 2. Managerial Implications \& Potential benefit

\begin{tabular}{|c|c|c|c|c|c|}
\hline Measurement & \multicolumn{2}{|c|}{ Before } & \multicolumn{3}{c|}{ After } \\
\hline EGI & Re-do PS & Ppk Value & Re-do PS & Ppk Value & Financial benefit \\
\hline HD465-7R & $18.51 \%$ & -0.06 & $0.00 \%$ & 18.32 & IDR. 3 billion \\
\hline PC1250 & $11.11 \%$ & -0.10 & $0.00 \%$ & 8.30 & IDR 16 Billion \\
\hline
\end{tabular}

\section{Conclusion}

The application of lean six sigma methodology can be beneficial for the division of PT PPN based on the analysis and discussion in this research. Some benefits among others can be listed as the following:

i The lean six sigma methodology can be applied to improve performance or quality of maintenance where in practice most quality management concepts such as lean six sigmas are applied only to manufacturing companies.

ii. After the performance improvement on the quality of maintenance on heavy equipment of PT PPN through the concept of quality management of lean six sigmas, there is an increase of sigma level (Ppk) or value of capability analysis especially on some heavy equipment which become pilot project implementation of improvement activity that is on EGI HD465 -7R \& PC1250. The results of the implementation of improved ideas that have been done with brainstorming methods provide improved performance on PS redo parameters on EGI HD465-7R \& PC1250.

iii. There are several factors causing the decrease of the quality of treatment performance or the high redo value of PS at the Bharinto site (BEKB) i.e. man power parameters such as the competence and knowledge of workers who are not in accordance with the standards, KPI review method that is not consistent, inspection technology that does not run optimally.

iv. From the improvement activities that have been done, it can have a big effect on the company's financial condition so that fewer units that experience breakdown it will have a big potential benefit for the company. It has some managerial implication or potential benefit for financial performance, improving in maintenance activities have potential saving for three billion rupiahs for HD4657R and 16 billion rupiahs for PC1250

v. Eventually, beside all the benefit mentioned, we also found limitation of this research. Only one division have been included as a case for this research and therefore, it is encouraged for future research that lean six sigma study should be applied to different divisions in the same company or the same division with different companies to analyze more on the impact of the application.

\section{References}

Al, Weber and Ron Thomas. 2005. Key performance indicators, measuring and managing the maintenance function. Ivara Corporation

APBI. 2016. Overview of Indonesia's Coal Mining Industry. Indonesian Coal Mining Association \& Ministry of Energy and Mineral Resources. https://www.indonesiainvestments.com/id/news 
Baluch, N. 2012. TPM and Lean Maintenance - A Critical Review. Interdisciplinary Journal of Contemporary Research In Business, Vol4, 2.

Bass, I., 2007. Six sigma Statistics with Excel and Minitab. Mc Graw Hill, New York, 159202.

Baumgartner, Jefrey (2012). The Step by Step Guide to Brainstorming, https://www.creativejeffrey.com/creative/brainstorming.php (observed 2 July 2017)

Chambers M., King S. 2006. Lean Six Sigma Maintenance. Paper presented at Certified Maintenance Reliability Practicioner 14th Annual Conference, Birmingham, Alabama.

Clark, Charles H. (2011). Brainstorming: The Dynamic New Way to Create Successful Ideas. Whitefish, MT: Literary Licensing.

Colton, Jim. 2013. Anderson-Darling, Ryan-Joiner, or Kolmogrow-Smirnov: Which Normality Test Is the Best. Minitab Statistical Software. https://www.minitab.com

Gulati, Ramesh. 2013.Maintenance and Reliability best practices 2nd Ed. Industrial press, Inc

Hendrardi, Tri. 2006. Statistik Six sigma dengan Minitab, Panduan Cerdas Initiatif Kualitas 6 sigma. Andi yogyakarta

Investmentmine (2016). www.infomine.com/investment (observed December 2016)

Jacobs, Roberts. 2011. Operations and supply chain managements 14th Global edition. Mc Graw Hill Education

Kannan S., Yanzhen L., Ahmed N., Akkad Z.2009a Developing Maintenance Value Stream Map. Departement of Industrial and Information Engineering, The University of Tennessee.

http://citeseerx.ist.psu.edu/viewdoc/similar?doi=10.1.1.136.2288\&type $=\mathrm{sc}$

Kannan S., Xueping L., Sawhney R. 2009b. Developing a value stream map to evaluate breakdown maintenance operations. International Journal of Industrial and systems Engineering Vol.4, No. 3.

Khaled, Masimuddin. 2013. Analysis of Six sigma in the Aerospace Industry. International Journal of Social, Behavioral, Educational, Economic, Business and Industrial Engineering, Vol:7, 12.

Mostafa S., Sang-Heon Lee, Jantanee D., Nicholas C., \& Hassan S. 2015a. Lean Thinking for a Maintenance Process. Journal of Production \& Manufacturing Research. 3, 236272.

Mostafa S., Jantanee D., \& Hassan S. 2015b. Lean Maintenance Roadmap. Paper presented at 2nd International Materials, Industrials, and Manufacturing Engineering Conference, MIMEC2015, Bali, Indonesia. 
Moubray, John. 2011. Reliability Centered maintenance (RCM) $2^{\text {nd }}$ Ed. Industrial Press Inc., New York.

Omar A., \& Mostafa Z., 2014. Implementation of Six sigma in Service Industry. Journal of Quality Measurement and Analysis (JQMA). 77-86.

Pedja Milosavljević. 2005. Six sigma Concepts in the Maintenance Process. International Journal of Industrial and systems Engineering

Rida, H. 2016. China Quarterly GDP Growth Weakest In A year. Trading Economics. https://tradingeconomics.com/china/gdp-growth

Robert B., Pojasek. 2003. Lean, Six sigma, and the systems approach: Management Initiatives for process Improvement. Environtmental Quality Managements. Wiley Periodical Inc.

Robertson A., 2016. Coal Prices Index 2016. http://www.infomine.com/investment/metalprices/thermal-coal-capp/

Smith, R., Hawkins B. 2004. Lean Maintenance. Linace house, jordan Hill, Oxford

Tenera A., Pinto L., 2013. A Lean Six sigma (LSS) project management improvement model. Paper presented at 27th IPMA World Congress, a Faculdade de Ciências e Tecnologia (FCT), da Universidade Nova de Lisboa (UNL), Caparica, 2829-516, Portugal.

Yulianto, Heri. 2015. PPN Maintenance Managements System Guidance Book. Plant System Development

Youssouf A., Rachid C., Contribution to The Optimization Of Strategy Of Maintenance By Lean Six sigma. 2014. Paper presented at $8^{\text {th }}$ International Conference on Material Sciences. University of Technology Gh., Asachi Iasi, Roumania.

Zapartas Z., 2012. Implementation of the Six Sigma Methodology in the Maintenance Process of Crown Hellas Can. 